\title{
Analysis of Nurse Characteristics with Work Motivation in Wamena Hospital
}

\author{
Moses Lamere ${ }^{1}$, Ratna \\ Wardani $^{2}$ \\ ${ }^{1}$ Master of Public Health Study \\ Program \\ ${ }^{2}$ Institute of Health Sciences \\ STRADA Indonesia \\ Email: \\ moseslamere80@gmail.com
}

Received: October $4^{\text {nd }} 2021$

Accepted: October $15^{\text {rd }} 2021$

Published : November $27^{\text {th }} 2021$

\begin{abstract}
Lately there has been attention to work dissatisfaction and declining quality. Most people find it difficult to motivate themselves, therefore it is not surprising that motivating others is a difficult and complicated task. Motivation indicates the process of movement, including the encouraging situation that arises within the individual, the behavior caused by the situation and the purpose or end of the movement or action. The purpose of this study was to analyze the relationship of nurse characteristics with work motivation in Wamena Hospital inpatient room.

This type of research is quantitative with an observational approach. The population is the entire nursing plant in Wamena Hospital with 186 people. Large samples were taken as many as 64 respondents. Sampling techniques used in this study is a simple random sampling technique.

Based on the results of the study it is known that there is a meaningful relationship between age, working period and position with work motivation. While there are several factors that are not related to work motivation, namely gender, education and marital status. The statistical test used is path analysis. Statistical tests can be concluded that there is a meaningful relationship to variables as follows: the characteristics of nurses that affect work motivation are age, years of service and position, while the characteristics of gender, education and marital status do not have a significant relationship with work motivation.

Based on the results of the study is expected to improve the ability and insight of nursing and motivation of work so that their productivity does not decrease. For example, give remuneration, promotion and periodic reward for outstanding nurses will encourage the motivation of nurse work to develop.
\end{abstract}

Keywords: Characteristics, nurse, work motivation

\section{Copyright (C) 2021 IIK STRADA Indonesia All right reserved.}

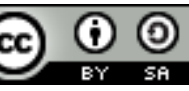

This is an open-acces article distributed under the terms of the Creative Commons AttributionShareAlike 4.0 International License.

\section{INTRODUCTION}

Health development aims to enable every population to be able to live healthy so that it can realize the optimal level of public health, which is one of the elements of general welfare of the national development goals, health service efforts are health efforts for all communities with community participation that includes efforts to improve (promotive), prevention (preventive), but does not mean 
not to make healing efforts (curative) and recovery (rehabilitative) thoroughly, integrated and sustainable (Notoatdmojo, 2012).

Public health services in Indonesia have successfully developed health services rapidly so as to make health services more evenly distributed. The quality of services is an important part that needs attention from health care providers. Packaging the quality of services to be produced should be one of the marketing strategies of hospitals that will sell services to service users. Hospital management must always strive to keep the service products offered can survive or be sustainable so as to seize market share (Muhith, 2017).

Lately there has been attention to work dissatisfaction and declining quality. Most people find it difficult to motivate themselves, therefore it is not surprising that motivating others is a difficult and complicated task. Motivation shows the process of movement, including the encouraging situation that arises in the individual, the behavior caused by the situation and the purpose or end of the movement or action (Muhith, 2016). The phenomenon of nurse work motivation is still low, where nurses have not been able to provide the best health services, this is seen still many complaints of patient and family dissatisfaction over the attitude and behavior of employees, especially nursing personnel in the inpatient room (M. Bara, 2014).

If you notice the number of nurses available every year increases, there is hardly even a turn over. This is because nurses usually resign because they have entered retirement age. To see the performance of Wamena Hospital can be seen data in 2018 shows that BOR 75.6, LOS 7.5, TOI 2.11, In 2019 BOR amounted to 70.45 LOS 7.58 TOI 2.67. In 2020 BOR 68.64 LOS 7.56 TOI 2.01. The decrease in BOR can be interpreted that there is a decrease in the quality of service, based on the observation of researchers, among others there is still the implementation of tasks that are not optimal from the nurses in addition such as arriving late, coming home early, the service is replaced by others or junior nurses, also complained by the recipient of services such as long service, unfriendly nurses, patients falling out of bed, giving unclear information to patients and families, providing services not wholeheartedly so many complaints such as; nurses are unfriendly, patients are dissatisfied with the service and many patients have not been treated.

Hospitals should be able to manage Human Health Resources (SDMK) optimally, resulting in good nursing services. The role of staffing management is very important which is how efforts must be made to obtain, foster, nurture and develop employees towards a capability in a pleasant working atmosphere with satisfactory working conditions and how to utilize employees efficiently with responsible quality. In this case SDMK is expected to have knowledge, skills and attitudes that are professional, productive and able to carry out tasks effectively and efficiently, to achieve these skills required high motivation from nurses.

Public health services in Indonesia have successfully developed health services rapidly so as to make health services more evenly distributed. The quality of services is an important part that needs attention from health care providers. Packaging the quality of services to be produced should be one of the marketing strategies of hospitals that will sell services to service users. Hospital management must always strive to keep the service products offered can survive or be sustainable so as to seize market share (Muhith, 2017).

The quality of hospital services can be assessed from three components of the management system, namely: 1) Structure, which includes: physical facilities, equipment, funds, health and nonhealth personnel as well as patients, 2) Processes, which include: hospital management, interpersonal management, technical management which are all reflected in medical and non-medical measures to patients, 3) Outcome, which is the final result of professional activities and actions towards patients (Muhith, 2017). Motivation is one of the processes by which the needs encourage a person to perform a series of activities that lead to the achievement of a particular goal. The right motivation of the employees will be encouraged to do their best in carrying out their duties because they believe that with the success of the organization achieving its goals and various objectives, the personal interests of the members of the organization will be maintained as well (Suhanda, 2017). The importance of nurse work motivation is needed to meet basic human needs so as to realize a good quality of service in accordance with patient expectations.

In an effort to improve the quality of health services, especially the performance of clinical services in general started by nurses through various forms of activities, such as: quality control groups, 
the application of nursing standards, problem-solving approaches, and nursing audits. Based on the Decree of the Minister of Health (Kepmenkes) No. 836/2005, SPMKK which later changed to The Development of Nurse and Midwife Performance Management (PMK) became a national policy to improve the quality and performance of nursing services both in hospitals and in puskesmas (Kuntjoro, 2005). According to Muninjaya (2009), hospitals and health centers as one of the sub-systems of health services provide two types of services to the community, namely health services and administrative services. Health services include medical services, medical rehabilitation and nursing services. Nurses as a profession in the field of health are required to provide professional services and oriented to the healthy paradigm in accordance with the paradigm of nursing owned, one of which is the development of health oriented to the improvement, maintenance, and protection of a healthy population, not just healing in the sick, so that efforts to provide health services are focused on preventive efforts to further improve and maintain for the healthy a productive and sick to be healthier (Hidayat, 2008). Nursing practice is basically to provide nursing care. The spectrum is wide, ranging from carrying out nursing studies, formulating nursing diagnosis, planning nursing actions, carrying out nursing actions (including medical actions that can be done by nurses (Soeroso, 2008).

The purpose of this study is to analyze the relationship of nurse characteristics with work motivation in wamena hospital inpatient room.

\section{MATERIALS AND METHODS}

This type of research is quantitative with an observational approach. The population is the entire nursing plant in Wamena Hospital hospital with 186 people. Large samples were taken as many as 123 respondents. Sampling techniques used in this study is a simple random sampling technique.

\section{RESULT}

The Distribution of Respondents' Frequency in this study was based on Age,Gender, Education, Marital Status. Working Period. Job Title and Motivation.

Table 1 Distribution of Respondents' Frequency by Age,Gender, Education, Marital Status. Working Period. Position and Motivation of Respondents in Nursing Staff at Wamena Hospital.

\begin{tabular}{clcc}
\hline No. & \multicolumn{1}{c}{ characteristic } & \multicolumn{1}{c}{$\%$} \\
\hline 1 & age & 24 & 37,5 \\
& $<30$ Years Old & 40 & 62,5 \\
& $>30$ Years Old & & \\
\hline $\mathbf{2}$ & gender & 9 & 14,1 \\
& man & 55 & 85,9 \\
& woman & & \\
& education & 54 & 84,4 \\
\hline $\mathbf{3}$ & D3 & 10 & 15,6 \\
& S1 & & \\
& Marital Status & 50 & 78,1 \\
\hline $\mathbf{4}$ & Married & 14 & 21,9 \\
& Unmarried & & \\
& Working Period & 22 & 34,4 \\
\hline $\mathbf{5}$ & Y Year & 42 & 65,6 \\
& $\geq 5$ Years & & 12,5 \\
& position & 8 & 87,5 \\
\hline $\mathbf{6}$ & Head of Room & 56 & 1,6 \\
& Implementing Nurse & & 62,5 \\
\hline $\mathbf{7}$ & Work Motivation & 1 & 35,9 \\
& low & 40 & 100 \\
\hline & enough & 23 & \\
& tall & 64 & \\
\hline & $\quad$ Total & & \\
\hline
\end{tabular}

Data Source : Primary Data processed 
Based on table 1 Frequency Distribution of Respondents Based on Age, the majority of the 64 respondents studied were 40 respondents $(62.5 \%)$ aged $>30$ years, the gender of female respondents was more dominant with 55 respondents $(85.9 \%)$, Education was able to it is known that of the 64 respondents studied, most of them have education with a D3 education level with 54 respondents (84.4\%), marital status of respondents with married status is more with 50 respondents $(78.1 \%)$. working period of respondents or nursing staff in Wamena Hospital, there are more groups that have a working period of 5 years, namely 42 respondents $(65.6 \%)$, From the position it can be seen that of 64 respondents, most of them are 56 respondents $(87.5 \%)$ are implementing nurses, while from work motivation it can be seen that of 64 respondents, most of them are 40 respondents $(62.5 \%)$ have good work motivation. enough.

Table 2 Results of Analysis of Nurse Characteristics Relationship With Work Motivation in Wamena Hospital.

\begin{tabular}{lllll}
\hline No. & variable & $\begin{array}{l}\text { Statistical } \\
\text { Values }\end{array}$ & P value & Abandon \\
\hline 1 & age & 7,341 & 0,025 & Significant \\
2 & gender & 1,103 & 0,576 & Insignificant \\
3 & education & 3,055 & 0,217 & Insignificant \\
4 & Marital Status & 4,850 & 0,088 & Insignificant \\
5 & Working Period & 8,550 & 0,014 & Significant \\
6 & position & 5,783 & 0,048 & Significant \\
\hline
\end{tabular}

Data Source : Primary Data processed

Based on the table above, it is known that the characteristics of nurses that affect work motivation are Age, Tenure and Position, while the characteristics of Gender, Education and Marital Status do not have a significant relationship with work motivation.

\section{DISCUSSION}

\section{Age Relationship with Work Motivation}

From the results of research conducted in Wamena hospital from 40 respondents with the age of $>30$ years it was seen that 21 respondents $(32,8 \%)$ have enough motivation and 19 respondents $(29,7 \%)$ have high work motivation. And of the 24 respondents with the age of < 30 years it was seen that 19 respondents $(29,7 \%)$ have enough work motivation and 4 respondents $(6,3 \%)$ have high work motivation. It means that those who have enough work motivation are respondents with the age of $>30$ years because they have more experience.

From the results of statistical tests, it can be concluded that there is a meaningful relationship between the age of respondents and the motivation of nursing workers in Wamena Hospital. Higher age can give rise to the ability of a person to make decisions the wiser, the more able to think rationally, the more able to control emotions and the more tolerance to the views of others (Robbin,, 2006).

\section{Sex Relations with Work Motivation}

In nursing the performance of nurses in carrying out nursing care may differ in relation to physical characteristics, characteristics and traits of different, gender is the classification of respondents consisting of men and women. From the results of research conducted in Wamena Hospital from 9 male respondents, it was seen that 7 respondents (10.9\%) have sufficient work motivation and 2 respondents $(3.1 \%)$ have high work motivation. And out of 55 female respondents, 33 respondents $(51,6 \%)$ have sufficient work motivation and 21 respondents $(32,8 \%)$ have high work motivation. From the results of statistical tests, it can be concluded that there is no meaningful relationship between the sex of respondents and the motivation of nursing workers in wamena.

The unproven relationship according to the author is due to the existing task of having standard procedures so that each nurse must be able to complete the task in accordance with the existing procedures without having to depend on the gender status. 


\section{Educational Relationship with Work Motivation}

From the results of research conducted at Wamena Hospital from 54 respondents with D3 education level, it was seen that 36 respondents (56.3\%) have sufficient work motivation and 17 respondents $(26,, 6 \%)$ have high work motivation. And out of 10 respondents with S1 education level, it was seen that 4 respondents or $(6.3 \%)$ have sufficient work motivation and 6 respondents $(9,4 \%)$ have high work motivation.

Hasil statistical test can be concluded that there is no meaningful relationship between the education of respondents and the motivation of nursing workers in wamena Hospital. The absence of such differences according to the researchers is due to that both D3 nursing and S1 Nursing, the education system has led to the task that must be done by nurses so that in carrying out their work motivation tasks do not differ significantly.

\section{Marital Status Relationship with Work Motivation}

From the results of research conducted at Wamena Hospital from 50 respondents with married status, it was seen that 30 respondents $(46,9 \%)$ have sufficient work motivation and 20 respondents (31.3\%) have high work motivation. And of the 14 respondents with unmarried status, it was seen that 10 respondents $(15.6 \%)$ have sufficient work motivation and 3 respondents $(4.7 \%)$ have high work motivation.

From the results of statistical tests, it can be concluded that there is no meaningful relationship between the marital status of respondents and the motivation of nursing workers in Wamena Hospital. These results show that in carrying out their work nurses act professionally in accordance with existing standards without involving personal factors, namely the marital status of each nurse.

\section{Working Period Relationship with Work Motivation}

From the results of research conducted at Wamena Hospital from 22 respondents with a working period of $<5$ years it was seen that 18 respondents $(28,1 \%)$ have a good work motivation and 3 respondents $(4,7 \%)$ have high work motivation. And of the 42 respondents with a working period of $>5$ years it was seen that 22 respondents $(34,4 \%)$ have sufficient work motivation and 20 respondents $(31,3 \%)$ have high work motivation.

From the results of statistical tests, it can be concluded that there is a meaningful relationship between the working period of respondents and the motivation of nursing workers in Wamena Hospital. According to the researchers the longer a person works, his ability will also develop, in addition to the level of seniority can also affect a person's motivation in work, for example to be a role model for his junior, thus demanding those who work longer can motivate others. One's work experience provides an understanding of the responsibilities of his work, so that the more understanding of his duties and responsibilities his work motivation will also develop optimally.

\section{Job Relationship with Work Motivation}

From the results of research conducted at Wamena Hospital from 8 respondents with positions as the head of the room, it was seen that 2 respondents $(3,1 \%)$ had sufficient work motivation and 6 respondents $(9,, 6 \%)$ have high work motivation. And of the 56 respondents with positions as implementing nurses, it appears that 38 respondents $(59,4 \%)$ have sufficient work motivation and 17 respondents $(26,6 \%)$ have high work motivation.

From the results of statistical tests, it can be concluded that there is a meaningful relationship between the position of respondents and the motivation of nursing workers in WamenaHospital. According to Muhith A., (2017), jabatan is the authority of responsibility in the organization so that itsobligations, rights, status and income are adjusted. Thus, it can be concluded that to increase the productivity of the company's work, high employee motivation is required and can be created through the fulfillment of material and non-material needs (Muhith A., 2017).

\section{Characteristic Relationship of Nurses with Work Motivation in Wamena Hospital.}

The results showed that from most of the motivation of respondents' work in the high category, the existence of motivation is necessary to encourage nurses in conducting documentation so that the provision of nursing care to patients is sustainable, precisely so as to improve the health status of 
patients and improve the quality of work produced so that satisfaction arises from customers and hospitals. Job satisfaction is expected to create a harmonious working relationship between employees and leaders so that hospital objectives can be achieved and succeed optimally. (Muhith, 2017). The results of this study are not in line with the research conducted by Sumirat Titis in 2014 which showed the value of significance so that it can be concluded that the hypothesis is accepted, which means there is a relationship of work motivation and quality of documenting nursing care.

Work motivation at Wamena Hospital is included in the high category, because each respondent's task which is the responsibility given by the hospital can be completed properly, not only that the respondent also moves all his efforts to advance the hospital. Respondents have an impulse from themselves to be able to work better and in accordance with hospital regulations so that they can fulfill and realize the goals of both the hospital and themselves. Good motivation can support and be one of the factors for nurses in carrying out good quality nursing care, for that it is important for nurses and other health workers who work in hospitals to be able to create and grow high motivation.

\section{CONCLUSION}

The conclusion obtained based on the research that the characteristics of nurses that affect work motivation are Age, Period of Work and Position, while the characteristics of Gender, Education and Marital Status do not have a significant relationship with work motivation.

Suggestions for further researchers are 1) For Hospitals: There is no attention or appreciation for nurses to improve nursing skills and insight and work motivation so that their productivity does not decrease, for example by providing opportunities to attend scientific meetings or seminars related to nursing, giving additional training or reallocation of functions so that they do not feel their work is not routine and boring. Given remuneration, promotion and rewards on a regular basis for nurses who excel will encourage the work motivation of nurses to develop more. 2.) For Educational Institutions; a. As input in teaching and learning activities related to hospital management. b. As a source of reading or reference to add insight for students, especially those related to nurse motivation 3.) For researchers; a. The results of this study can be used as a comparison in making the same research, both in terms of the number of samples, research methods, research materials and others. b. If other researchers want to do the same research as this research, it is expected to consider adding the characteristics of the respondents and other variables related to the motivation of nurses.

\section{ACKNOWLEDGMENTS}

For this reason, the researcher would like to thank:

1. Prof. Dr. H. Sandu Siyoto, S.Sos., SKM., M.Kes, as Chancellor of IIK STRADA Indonesia

2. Dr. Yuly Peristiowati, S.Kep Ns., M.Kes., as Director of the Postgraduate Public Health Sciences IIK STRADA Indonesia

3. Ratna Wardani, S.Si, MM., as Advisor 1 who has guided researchers in completing this thesis well

4. Head of the Jayawijaya District Health Office, dr. Willy E. Mambieuw, Sp.B who has supported and provided recommendations in research.

5. Director of Wamena Hospital, dr. Felly G. Sahureka, Sp.PK who has given permission to researchers to conduct research.

6. Beloved wife who has given motivation and enthusiasm and helped in the completion of this thesis

7. The researcher's beloved family as a form of respect and devotion to the researcher, and thank you for the prayers that are always offered and the encouragement and enthusiasm

\section{REFERENCES}

A Nasir., A Muhith \& ME Ideputri (2011). Buku Ajar Metodologi Penelitian Kesehatan, Yogyakarta: NuhaMedika.

Artini, I.W., Suarjana, I. P., Wijaya Ganda. (2012) Hubungan Penerapan Manajemen Puskesmas dan Komitmen Kerja dengan Mutu Pelayanan Pengobatan di Puskesmas Kabupaten Karangasem, Bali. Public Health and Preventive Medicine Archive, Vol. 4 No.1, Juli 2016. 
As'ad, M. (2014). Seri Ilmu dan Sumber Daya Manusia, Psikologi. Industri. Yogyakarta : Penerbit Liberty.

Depkes R.I., (2008). Profil Kesehatan Indonesia. Jakarta.

E Rahmawati (2016), Hubungan motivasi perawat dengan pelaksanaan pendokumentasian asuhan keperawatan di Ruang Rawat Inap Sleman.

Ferdiansyah, A., Muhith, A., Saputra, M . H., Fenty. (2017). Gambaran Tingkat Turnover Perawat, Motivasi, Dan KinerjaPerawat Di RumahSakit Islam Hasanah Mojokerto. Prosiding Seminar Nasional Hasil Penelitian Dan Pengabdian Masyarakat Seri Ke-1 Tahun 2017.

Friedman, M.M. (2018). Keperawatan Keluarga Teori dan Praktik. Edisi 3. Jakarta: EGC

Hidayat A. A. (2012), Riset Keperawatan dan tekhnik penulisan Ilmiah. Jakarta, Salemba Medika.

Kuncoro T., (2015). Pengembangan Manajemen Kinerja Perawat dan Bidan. Sebagai Strategi dalam Peningkatan Mutu klinis. JMK Vol. 18/No.93/September/2005

M Bara, B Suryati (2015), Hubungan motivasi perawat dengan pelaksanaan pendokumentasian asuhan keperawatan di Ruang Rawat Inap RSUD Pasar Rebo.

Menik, K. (2015). Hubungan Motivasi Dan Komitmen Kerja Perawat Dengan Penerapan Keselamatan Pasien Di Ruang Intensif Rsup Sanglah Denpasar .Skripsi, Denpasar, 2015.

Muhith, A (2016), Hubungan motivasi dan gaya kepemimpinan kepala ruangan dengan prestasi kerja perawat di RS Semen Gresik.

Muhith, A. (2017). Pengembangan Model Mutu Asuhan Keperawatan, Yogyakarta: CV Threepreneur.

Muhith, A., Saputra, M. H., \& Nursalam, N. (2017). Marketing Mix By Bed Occupancy Ratio (BOR). Jurnal Ners, 8(1), 135-141.

Muninjaya, A. A. Gde (2009). Manajemen Kesehatan (Edisi 2). Penerbit: EGC

Notoatmodjo, S. (2012). Pendidikan dan Perilaku Kesehatan Jakarta: Rineka Cipta.

Notoatmodjo, S.(2011). Metodologi Penelitian Kesehatan. Jakarta: PT Rineka Cipta.

Nursalam, (2013).Metodologi Penelitian Ilmu Keperawatan: Pendekatan Praktis, Edisi 3, Jakarta: Salemba Medika.

Robbin, S.P., (2006). Perilaku Organisasi, Konsep-Kontroversi-Aplikasi, Edisi Bahasa Indonesia, Jakarta: PT.Prenhalindo.

Soeroso, S. (2018). Manajemen Sumber Daya Manusia di Rumah Sakit. EGC, Jakarta 